\title{
Underwater noise in the Slovenian Sea
}

\section{Podvodni hrup v slovenskem morju}

\author{
Andreja Popit* \\ Institute for Water of the Republic of Slovenia, Ljubljana, Slovenia \\ *andreja.popit@izvrs.si
}

\begin{abstract}
Continuous underwater noise has been monitored in the Slovenian sea near the lighthouse foundation at Debeli Rtič since February 2015, according to the EU Marine Strategy Framework Directive (MSFD). Anthropogenic noise sources (e.g. seawater densities, dredging activities and cleaning of the seafloor) and meteorological noise sources (e.g. wind speed and precipitation) were analysed in relation to the measured underwater noise levels using several graphical and statistical methods. The results of this study showed that average equivalent continuous underwater noise levels were, by $11 \mathrm{~dB}\left(L_{e q, 63 \mathrm{~Hz}}\right)$ and $5 \mathrm{~dB}\left(L_{e q, 125 \mathrm{~Hz}}\right)$, higher in the intervals when dredging activities took place than in the intervals when these activities were absent. Variation in underwater noise levels was partly related to the variation of the ship densities, which could be explained by the relatively small acoustic propagation in the shallow seawater. Precipitation level did not indicate any significant association with the variations in continuous underwater noise levels, though some larger deviations in the wind speed were found to be associated with the larger fluctuations in continuous underwater noise levels.
\end{abstract}

Keywords: underwater noise, shallow sea, measuring equipment, natural and anthropogenic sound sources

\section{Introduction}

The background or ambient noise in the seas and oceans is composed of natural (i.e. meteorological (wind speed, surface waves, precipitation), geological (tectonic processes) and biological) and anthropogenic (i.e. marine traffic) noise sources. It varies with the location and frequency of underwater sound. In regions with high

\section{Povzetek}

V slovenskem morju izvajamo kontinuirne meritve podvodnega hrupa ob svetilniku pri Debelem rtiču od februarja 2015. Meritve potekajo v skladu z Okvirno direktivo o morski strategiji. Za analizo antropogenih virov hrupa (gostota ladij, poglabljanje in čiščenje morskega dna) in meteoroloških virov hrupa (hitrost vetra in padavine) $v$ povezavi $z$ izmerjenimi ravnmi podvodnega hrupa smo uporabili grafične in statistične metode. Rezultati te študije so pokazali, da so bile povprečne ekvivalentne ravni kontinuirnega podvodnega hrupa za $11 \mathrm{~dB}$ (Leq, $63 \mathrm{~Hz}$ ) in $5 \mathrm{~dB}$ (Leq,125 Hz) višje v času, ko so potekale dejavnosti poglabljanja, kot v času, ko so teh dejavnosti ni bilo. Nihanja ravni podvodnega hrupa so bila $v$ manjši meri povezana $z$ nihanji gostote ladij, kar lahko razložimo $\mathrm{z}$ relativno majhno akustično propagacijo v plitvem morju. Padavine niso bile veliko povezane $z$ nihanji ravni podvodnega hrupa, medtem ko so bila nekatera večja nihanja hitrosti vetra povezana $z$ večjimi nihanji ravni kontinuirnega podvodnega hrupa.

Ključne besede: podvodni hrup, plitvo morje, merilna oprema, naravni in antropogeni viri zvoka

shipping densities, the frequency band between $10 \mathrm{~Hz}$ and $200 \mathrm{~Hz}$ is primarily associated with shipping activity, constituting the largest anthropogenic contribution to the underwater ambient sound [1-11].

Most of the noise power radiated into the water by surface ships comes from propeller cavitation $[1,4,12]$. Propeller noise is generated through several cavitation noise mechanisms: 
tip vortex cavitation, different types of blade cavitation, hub vortex cavitation, pressure pulses due to wake inhomogeneity at the propeller plane, pressure pulses generated by the rotating propeller blades and singing due to resonance between blade natural frequencies and trailing edge vortices. Some vessels emit strong structural noise radiation arising from their hydraulic systems, gears, compressors or other noisy machinery [4].

An increase in the low-frequency ocean ambient noise levels was observed between 1963 and 2001 on the continental slope of Point Sur, California [7, 8, 13], between 1964 and 2004, westwards of the San Nicolas Island, California [14] and between 1978 and 1986 in the Northeast Pacific Ocean [15]. This was related to the shipping vessel traffic. The number of commercial vessels in the world's oceans approximately doubled and the gross tonnage quadrupled between 1965 and 2003, with a corresponding increase in horsepower of the vessels. Increases in commercial shipping are believed to account for the observed increase in the low-frequency ambient noise [14].

More recently, between 2006 and 2016, observations made in the Northeast Pacific, Equatorial Pacific and in the South Atlantic Ocean show a slightly decreasing trend in low-frequency ambient noise levels $[16,17]$. This trend may be attributed to the fact that world vessel size and gross tonnage have increased considerably over the recent years, while the number of vessels has decreased [18-21].

Wind-generated sea-surface agitation governs much of the ambient noise in the frequency band between $200 \mathrm{~Hz}$ and 100,000 Hz. Wind-generated noise is largely the consequence of bubbles created in the process of wave-breaking. At lower frequencies $(<500 \mathrm{~Hz})$, the oscillation of bubble clouds themselves are considered to be the source of the sound $[22,23]$ while, at higher frequencies $(>500 \mathrm{~Hz})$, the excitation of resonant oscillations by individual bubbles generates the sound [7, 24, 25].

At very high frequencies, $\sim 100,000 \mathrm{~Hz}$, thermal noise generated by the random motion of water molecules begins to dominate. The thermal noise spectral density at $100,000 \mathrm{~Hz}$ is 20-25 dB re $1 \mu \mathrm{Pa}^{2} / \mathrm{Hz}$ [7].

Rain can produce a peak in the ambient sound pressure spectral density (around $60 \mathrm{~dB}$ re $1 \mu \mathrm{Pa}^{2} / \mathrm{Hz}$ ) in the vicinity of $15 \mathrm{kHz}$, corresponding to rain rates ranging from $2 \mathrm{~mm} / \mathrm{h}$ to $5 \mathrm{~mm} / \mathrm{h}$, measured at different wind speeds $[7,26]$.

Underwater ambient noise is generated not only by the combination of environmental sea state and anthropogenic contributions (e.g. shipping), but also by significant amounts of biological noise from fish, invertebrates and whales. Biological noise may generate major background noise in some areas. Marine mammals, such as whales and dolphins, rely on sound to communicate with each other, locate their prey and find their way over long distances. All these activities, critical to their survival, are being interfered with by the increasing levels of noise from ships [1, 4, 27-33]. The European Commission's Marine Strategy Framework Directive (MSFD) 2008/56/EC [34] and International Maritime Organization( IMO) guidelines for the reduction of underwater noise from commercial shipping [35] have addressed underwater noise pollution from shipping, as well as the promotion of the use of the appropriate mitigation measures.

The EC MSFD 2008/56/EC [34] guidelines require the Member States to prepare a Marine Management Plan. These requirements were incorporated in Slovenian law by passing the Water Act [36] and by the Decree on the detailed content of the Marine management plan [37]. According to this legislation, Slovenia started to monitor continuous underwater noise near the lighthouse foundation at Debeli Rtič since February 2015.

The aim of our study was to analyse continuous underwater noise measurements from 2015 until 2018. The measured ambient lowfrequency noise levels were most probably due to anthropogenic activities such as marine traffic, dredging activities and cleaning of the seafloor, as well as to meteorological factors such as precipitation and wind. These levels were analysed through the proposed methodology and results of this study were discussed in this article. 


\section{Materials and methods}

\section{Underwater noise measuring station and measured quantities}

A permanent underwater noise measurement station was established on the concrete foundation of a masonry lighthouse $300 \mathrm{~m}$ off the coast at Debeli Rtič, Slovenia in February 2015 (Figure 1a). The coordinates of the lighthouse are Lat.: $45^{\circ} 35^{\prime} 28.2^{\prime \prime} \mathrm{N}$, Lon.: $13^{\circ} 41^{\prime}$ 59.1" E. The associated measuring equipment was composed of a spherical omnidirectional hydrophone (Type 8105, Bruel \& Kjaer ) installed at a depth of $4 \mathrm{~m}$ (Figure 1b) (sea depth at that location was $5 \mathrm{~m}$ ). The hydrophone is connected to a sound analyser of Type 2250 Bruel $\&$ Kjaer, which includes a sound level meter and an octave-based frequency analyser, operating in the frequency band of $6.3-20 \mathrm{kHz}$. The hydrophone with a cable was installed through a metal pipe $1 \mathrm{~m}$ away from the lighthouse foundation to a depth of approx. $1 \mathrm{~m}$ above the seabed, as shown in Figure 1b [38]. A sound analyser was closed inside the lighthouse in a waterproof casing, according to the standard National Electrical Manufacturers Association (NEMA) IP65 protocols, and maintaining resistance to water jets was ensured. The measuring system was connected to the batteries that were charged by a solar panel $[38,39]$.
The mathematical definition of the measured equivalent continuous sound level (Eq. 1) (also called time-average sound level), $L_{e q}$ is 20 times the logarithm to base 10 of the ratio of the root mean square sound pressure $\left(p_{r m s}\right)$ during a time interval to the reference sound pressure $\left(p_{0}\right.$, which is $\left.1 \mu \mathrm{Pa}\right)[40]$ :

$$
L_{e q}(t)=10 \log _{10}\left(\frac{p_{r m s}}{p_{0}}\right)^{2}=20 \log _{10}\left(\frac{p_{r m s}}{p_{0}}\right)
$$

Root mean square of the sound pressure level ( $p_{\text {rms }}$ ) (Eq. 2) in Pascals (Pa) [41] can be represented as:

$p_{r m s}=\left(\frac{1}{\left(t_{2}-t_{1}\right)} \int_{1}^{2} p(t)^{2} \mathrm{~d} t\right)^{\frac{1}{2}}$

where, $\mathrm{P}_{\text {rms }}$ or the mean square sound pressure is the time integral of squared sound pressure over a specified time interval divided by the duration of the time interval; and $t_{1}$ and $t_{2}$ are the start and stop times of the time interval over which the mean is evaluated.

The RMS sound pressure is calculated by first squaring the values of sound pressure, averaging over the specified time interval and then taking the square root.

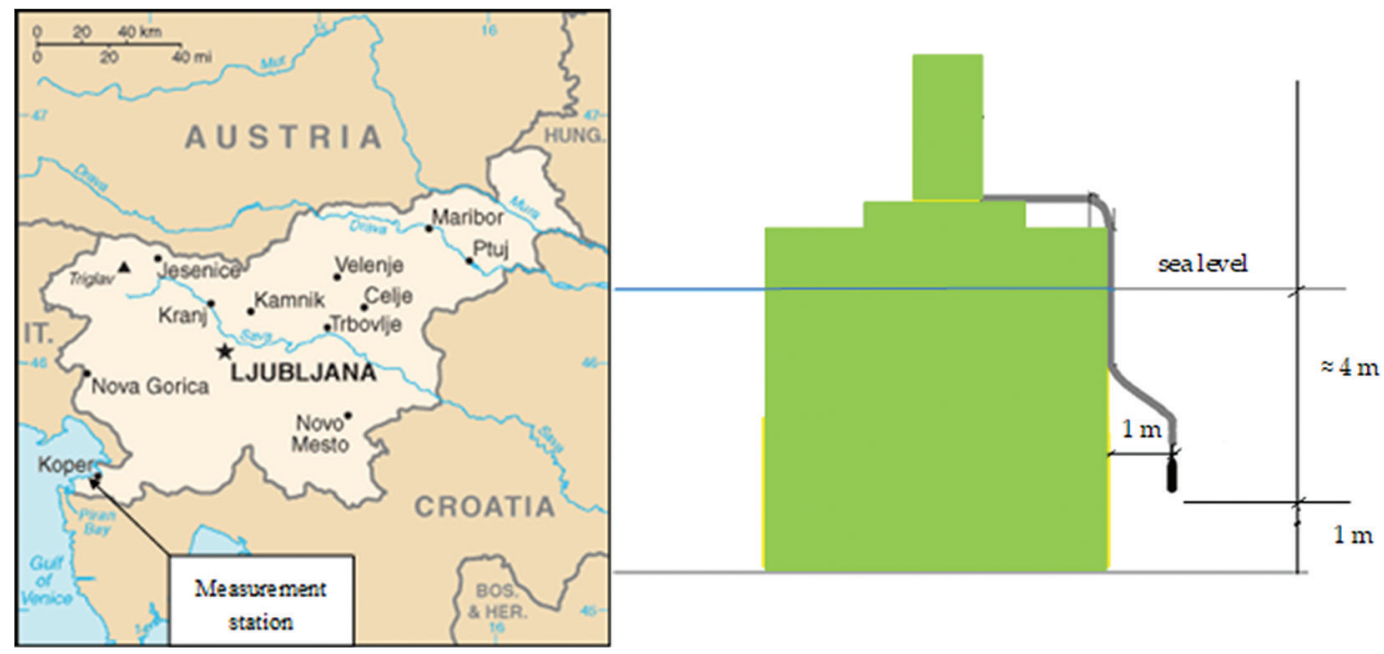

(a)

Figure 1: Location of the permanent underwater noise measurement station near Debeli Rtič in the Slovenian Sea (A) and a sketch of the lighthouse at Debeli Rtič on which the measuring equipment is installed showing the hydrophone at a depth of $4 \mathrm{~m}$ (sea depth at the location is $5 \mathrm{~m}$ ) (B) [38]. 
Frequency analysis software enables derivations of the equivalent continuous sound levels in 1/3-octave band with centre frequencies between $6.3 \mathrm{~Hz}$ and $20 \mathrm{kHz}$, in the resolution of $10 \mathrm{~s}$. Daily arithmetic mean values were calculated and recorded on a hard disc of 1 Terabyte (TB). The memory capacity of the disc enables recordings for 75 days.

Measured data were transferred, displayed and analysed using BZ-5503 Measurement Partner Suite [40] software. This software can be used for data archival, data preview and data export, for post-process and export to other formats, online data display and remote access and operation, as well as for maintenance of the sound level meter software.

With BZ-5503 Measurement Partner Suite, daily equivalent continuous sound levels $\left(L_{e q}\right.$ values) in the 1/3-octave band with centre frequencies between $6.3 \mathrm{~Hz}$ and $20 \mathrm{kHz}$ were analysed.

\section{Methodology used for processing continuously measured data}

The first step in data processing was, in our case, done by the sound analyser of Type 2250 (Bruel \& Kjaer ), which calculates equivalent continuous sound levels in 1/3-octave bands. Then we proceeded with the second step in data processing, to calculate the annual average of the continuous sound level.

For monitoring and assessing anthropogenic continuous low-frequency sound in water (D11C2) we used annual average of the squared sound pressure in 1/3-octave bands, one centred at $63 \mathrm{~Hz}$ and the other at $125 \mathrm{~Hz}$, both expressed as a level in decibels in units of $\mathrm{dB}$ re $1 \mu \mathrm{Pa}$, according to the requirements of the Commission Decision EU/2017/848 [42]. The unit of measurement used for the criteria D11C2 is the annual average of the continuous sound level per unit area; proportion (percentage) of extent in square kilometres of the assessment area.

For this purpose we used the arithmetic mean $(A M)$ in time $T$ [43] (Eq. 3), which shows compatibility with $L_{e q}$ metric:

$$
A M(T)=\frac{1}{N(T)} \sum_{\mathrm{n}=1}^{N(T)} p_{\mathrm{n}}(T)
$$

where $N(T)$ is the number of snapshots of duration $T$ in 1 year (Eq. 4) (assuming that the data are continuous, and contain no gaps for an entire year):

$$
N(T)=\frac{1 \text { year }}{T}
$$

where $p_{n}(T)$ is the mean square sound pressure at the $n$-th snapshot of duration $T$.

The arithmetic mean is expressed as sound pressure level (SPL) (Eq. 5) in $\mathrm{dB}$ re $\mu \mathrm{Pa}[43]$ :

$$
L_{A M}(T)=10 \log _{10} \frac{A M(T)}{p_{r e f}^{2}}
$$

where $p_{\text {ref }}=1 \mu \mathrm{Pa}$.

Annual averages of the continuous sound level and standard deviation (STDEV) for $1 / 3$-octave bands with centre frequencies of $63 \mathrm{~Hz}$ and $125 \mathrm{~Hz}$ were calculated using daily averages, which were calculated using the sound analyser.

The results of the underwater noise measurements from the measuring station at Debeli Rtič were analysed and reviewed using the BZ-5503 Measurement Partner Suite Software [39]. The equivalent unweighted continuous noise levels within 1/3-octave frequency bands with centre frequencies of $63 \mathrm{~Hz} L_{e q, 63 \mathrm{~Hz}}$ and $125 \mathrm{~Hz} L_{e q, 125 \mathrm{~Hz}}$ (in $\mathrm{dB}$ ), according to the MSFD 2008/56/EC [34], were exported into an excel spreadsheet for further analyses. The underwater noise data were available at half-hour intervals for the following periods: from 13 February 2015 to 5 May 2015; 26 September 2015 to 31 December 2015; 18 August 2016 to 1 November 2016; 6 July 2017 to 27 August 2017; and 18 August 2018 to 31 December 2018.

Average hourly values of equivalent continuous underwater noise levels in 1/3-octave bands with centre frequencies of $63 \mathrm{~Hz}$ and $125 \mathrm{~Hz}$ for each measuring period were prepared and presented on diagrams.

Asymmetry (A) (Eq. 6) was used to test the normality of the distribution of underwater noise levels. Asymmetry was 
used to indicate the direction of data asymmetry [44]:

$A=$

where $m_{2}$ and $m_{3}$ are the second and third moments around the average.

The $j$-th moment is calculated by the Eq. (7), represented below [44]:

$m_{j}=\frac{\sum_{i=1}^{n}\left(x_{i}-\bar{x}\right)^{j}}{n}$

When $A$ is 0 , the data set is symmetric to its mean and the data are distributed symmetrically or normally (Gaussian distribution). At $A<0$ the data are asymmetric to the left and at $A>0$ the data are asymmetric to the right. If $A<-1$ or $A>1$ the distribution is very asymmetric.

If $A$ is between -1 and -0.5 or between 0.5 and 1 , the distribution is moderately asymmetric. If $A$ falls between -0.5 and 0 or between 0 and 0.5 , the distribution is approximately symmetric.

The statistics were calculated in Excel (Microsoft).

\section{Methodology for the analysis of anthropogenic sources (ship densities, dredging and cleaning activities) of the underwater noise in the canals of the Port of Koper}

Marine traffic in the sea is monitored with the Automatic Information System (AIS). Obtained AIS data concerning locations of the ships were analysed in the North Adriatic Sea for 2015, 2016, 2017 and 2018 to prepare hourly data on the ship densities in four different areas around the underwater noise measuring station at the lighthouse at Debeli Rtič, Slovenia. These four areas were namely within a radii of 2 nautical miles (NM) and 5 NM from the measuring station, in the Gulf of Trieste and the Gulf of Venice. Data on ship densities were prepared for each period during which underwater noise levels were recorded.

Average hourly ship densities in all four areas around the measuring station, for each period in which underwater noise levels were recorded, were presented graphically in combination with the average hourly continuous underwater noise levels in 1/3-octave bands with centre frequencies of $63 \mathrm{~Hz}$ and $125 \mathrm{~Hz}$. Asymmetry $(A)$ was used to test the normality of the distribution of ship densities.

Dredging activities were carried from 7 September 2015 to 26 October 2015 from 7:00-21:00 h, while cleaning activities of the seafloor in the canals of the Port of Koper were carried out from 18 August 2016 to 31 August 2016, and from 22 September 2016 to 29 September 2016 from 8:00-16:00 h (Table 1). Dredging was carried out in the sea with a dredger and a trailed harrow for levelling the seabed, while the cleaning work was carried out from the mainland with the help of the Link-Belt LS-108B excavator crane.

On the diagram concerning ship density in the four areas around the measuring station in combination with the average hourly continuous underwater noise levels in 1/3-octave bands with centre frequencies of $63 \mathrm{~Hz}$ and $125 \mathrm{~Hz}$, were drawn red arrows indicating dredging and cleaning activities.

Average equivalent continuous underwater noise levels during dredging and cleaning activities were analysed. Separately, average equivalent continuous levels of underwater noise were analysed at the time when there were no anthropogenic activities (Table 1). These analyses were performed to check whether the average values (AVE) of equivalent continuous underwater noise levels, in 1/3-octave bands with centre frequencies of $63 \mathrm{~Hz}$ and $125 \mathrm{~Hz}$ at the time of dredging and cleaning activities, were higher than at the time when these activities were not being executed.

\section{Methodology for the analysis of meteorological sources of the underwater noise}

In this section, wind speed and precipitation were analysed as meteorological sources of underwater noise. Half-hourly data on wind speeds $(\mathrm{m} / \mathrm{s})$ from the Piran buoy (Lon.: 13.5454 ${ }^{\circ}$, Lat.: $45.5481^{\circ}$, altitude: $0 \mathrm{~m}$ ) and half-hourly data on precipitation ( $\mathrm{mm}$ ) from the meteorological station in the Port of Koper (Lon.: $13.7448^{\circ}$, Lat.: $45.5645^{\circ}$, Altitude: $2 \mathrm{~m}$ ), in the periods in which underwater noise 
Table 1: Periods with and without the anthropogenic activity

\begin{tabular}{lcc}
$\begin{array}{l}\text { Type of anthropogenic } \\
\text { activity }\end{array}$ & $\begin{array}{c}\text { Periods with the } \\
\text { anthropogenic activity } \\
\text { Dredging }\end{array}$ & $\begin{array}{c}\text { Periods without any } \\
\text { anthropogenic activity }\end{array}$ \\
& $\begin{array}{c}(7: 09.2015-26.10 .2015 \\
18.08 .2016-31.08 .2016\end{array}$ & $26.09 .2015-26.10 .2015(22: 00-6: 00 \mathrm{~h})$ \\
Cleaning of the seafloor & $22.09 .2016-29.09 .2016$ & $22.09 .2016-29.09 .2016(17: 00-7: 00 \mathrm{~h})$ \\
& $(8: 00-16: 00 \mathrm{~h})$ & 8 \\
\hline
\end{tabular}

levels were recorded, were obtained from the Environmental Agency of the Republic of Slovenia (ARSO).

Average hourly wind speeds and precipitation levels in the individual periods were calculated and presented graphically in combination with average hourly continuous underwater noise levels in 1/3-octave bands with central frequencies of $63 \mathrm{~Hz}$ and $125 \mathrm{~Hz}$. Furthermore, asymmetry $(A)$ was used to test the normality of the distribution of the average hourly wind speeds and average hourly precipitation data.

\section{Results}

The average continuous underwater noise levels in the 1/3-octave bands with centre frequencies of $63 \mathrm{~Hz}\left(L_{e q, 63 \mathrm{~Hz}}\right)$ and $125 \mathrm{~Hz}\left(L_{e q, 63 \mathrm{~Hz}}\right)$ in $\mathrm{dB}$ re $1 \mu \mathrm{Pa}$, average ship densities in the four areas around the measuring station $\left(\rho_{L, 2 \mathrm{NM}}\right.$, $\rho_{L, 5 \mathrm{NM}}, \rho_{L \text {, Trieste. }}$ and $\left.\rho_{L \text {, venice }}\right)$, average wind speeds $\left(v_{v}\right)$ in $\mathrm{m} / \mathrm{s}$ and average precipitation $\left(h_{p}\right)$ in $\mathrm{mm}$ in each measurement period are presented in Table 2.

The average $L_{e q, 63 \mathrm{~Hz}}$ and $L_{e q, 125 \mathrm{~Hz}}$ levels measured in the Slovenian Sea during the period 2015-2018 (Table 2) were 82.8-101.1 dB re $1 \mu \mathrm{Pa}$ and 83.9-98.1 dB re $1 \mu \mathrm{Pa}$, respectively. The ship densities were 2-252. The average wind speed was $1.8-4.6 \mathrm{~m} / \mathrm{s}$ and the average precipitation was $0.02-0.07 \mathrm{~mm}$.

The $L_{e q, 125 \mathrm{~Hz}}$ data were distributed close to the normal (Gaussian) distribution in all measuring periods (they were slightly asymmetric to the right or left), as the value of $A$ was close to 0 (Table 3 ). The $L_{e q, 63 \mathrm{~Hz}}$ data were distributed moderately asymmetrically to the right
( $A=0.5-1.1$ ), except for the period from 18 August 2016 to 1 November 2016, when they were distributed approximately symmetrically ( $A=-0.4)$ (Table 3).

The $\rho_{L, 2 \mathrm{NM}}$ data were distributed moderately asymmetrically to the right in all measuring periods and the $\rho_{L, 5 \mathrm{NM}}$ data and $\rho_{L \text {, Trieste }}$ were distributed very asymmetrically to the left in the first two periods, very asymmetrically to the right in the third and fifth periods and approximately symmetrical in the fourth period. The $\rho_{L \text {, venice }}$ data were moderately asymmetrically distributed to the left in the first two periods, and moderately asymmetrically to the right to approximately symmetrically in the other periods (Table 3).

The $v_{v}$ data were distributed very asymmetrically to the right in all measuring periods, except in the period from 18 August 2016 to 1 November 2016, in which they were distributed moderately asymmetrically to the right. The $h_{p}$ data were distributed very asymmetrically to the right in all measuring periods (Table 3 ).

The relationship of the measured ambient low-frequency noise levels with the anthropogenic activities (ship densities, dredging and cleaning activities) is shown in the diagrams (Figures 2-6) of the average hourly ship densities in the four areas around the underwater noise measuring station $\left(\rho_{L, 2 \mathrm{NM}}, \rho_{L, 5 \mathrm{NM}}, \rho_{L \text {, Trieste. }}\right.$ and $\rho_{L \text {, venice }}$ ) in combination with the average hourly continuous underwater noise levels in $1 / 3$-octave bands with centre frequencies of $63 \mathrm{~Hz}$ and $125 \mathrm{~Hz}$. Blue curve presents $L_{e q, 63 \mathrm{~Hz}}$ black curve presents $L_{e q, 125 \mathrm{~Hz}}$, violet curve presents ship density $2 \mathrm{NM}$ from the measuring station, yellow curve presents ship density $5 \mathrm{NM}$ from the measuring station, green curve presents ship density in the Gulf of Trieste and 
Table 2: The results of AVE and STDEV calculations of $L_{\text {eq, } 63 \mathrm{~Hz}^{\prime}} L_{\text {eq, } 125 \mathrm{~Hz}^{\prime}} \rho_{L, 2 \mathrm{NM}^{\prime}} \rho_{L, 5 \mathrm{NM}^{\prime}} \rho_{L, \text { Trieste }} \rho_{L, \text { venice, }}$ dredging, cleaning activity, $v_{v}$ and $h_{p}$ in different measuring periods

\begin{tabular}{|c|c|c|c|c|c|}
\hline $\begin{array}{l}\text { Average of } \\
\text { AVE and } \\
\text { STDEV }\end{array}$ & $\begin{array}{c}\text { From } \\
13.02 .2015 \text { to } \\
05.05 .2015\end{array}$ & $\begin{array}{c}\text { From } \\
26.09 .2015 \text { to } \\
31.12 .2015\end{array}$ & $\begin{array}{c}\text { From } \\
\text { 18.08.2016 to } \\
01.11 .2016\end{array}$ & $\begin{array}{c}\text { From } \\
06.07 .2017 \text { to } \\
27.08 .2017\end{array}$ & $\begin{array}{c}\text { From } \\
18.08 .2018 \text { to } \\
31.12 .2018\end{array}$ \\
\hline $\begin{array}{l}A V E \& S T D E V \\
\text { of } L_{e q, 63 \mathrm{~Hz}}\end{array}$ & $83.0 \pm 15.1$ & $82.8 \pm 10.8$ & $101.1 \pm 6.9$ & $86.7 \pm 7.7$ & $88.6 \pm 5.7$ \\
\hline $\begin{array}{l}A V E \& S T D E V \\
\text { of } L_{e q, 125 \mathrm{~Hz}}\end{array}$ & $89.0 \pm 13.1$ & $83.9 \pm 2.5$ & $97.5 \pm 6.8$ & $85.2 \pm 3.3$ & $98.1 \pm 3.9$ \\
\hline $\begin{array}{l}A V E \& S T D E V \\
\text { of } \rho_{L, 2 \mathrm{NM}}\end{array}$ & $2 \pm 2$ & $3 \pm 2$ & $5 \pm 3$ & $5 \pm 3$ & $5 \pm 3$ \\
\hline $\begin{array}{l}A V E \& S T D E V \\
\text { of } \rho_{L, 5 \mathrm{sm}}\end{array}$ & $24 \pm 9$ & $37 \pm 7$ & $45 \pm 6$ & $52 \pm 6$ & $52 \pm 8$ \\
\hline $\begin{array}{l}A V E \& S T D E V \\
\text { of } \rho_{L, \text { Trieste }}\end{array}$ & $35 \pm 13$ & $50 \pm 10$ & $58 \pm 8$ & $71 \pm 9$ & $70 \pm 11$ \\
\hline $\begin{array}{l}A V E \& S T D E V \\
\text { of } \rho_{L, \text { Venice }}\end{array}$ & $117 \pm 52$ & $186 \pm 51$ & $252 \pm 53$ & $246 \pm 48$ & $247 \pm 56$ \\
\hline $\begin{array}{l}A V E \& S T D E V \\
\text { of } v_{v}\end{array}$ & $4.6 \pm 3.3$ & $4.5 \pm 3.8$ & $4.6 \pm 2.7$ & $1.8 \pm 1.2$ & $2.0 \pm 1.6$ \\
\hline $\begin{array}{l}A V E \& S T D E V \\
\text { of } h_{p}\end{array}$ & $0.02 \pm 0.13$ & $0.04 \pm 0.35$ & $0.07 \pm 0.61$ & $0.02 \pm 0.31$ & $0.05 \pm 0.32$ \\
\hline
\end{tabular}

Table 3: The results of asymmetry $(A)$ calculations of $L_{\text {eq,63 Hz' }} L_{\text {eq, } 125 \mathrm{~Hz}} \rho_{L, 2 \mathrm{NM}} \rho_{L, 5 \mathrm{NM}} \rho_{L, \text { Trieste }} \rho_{L, \text { venice, }}$ dredging, cleaning activity, $v_{v}$ and $h_{p}$ in different measuring periods

\begin{tabular}{lccccc} 
Asymmetry & $\begin{array}{c}\text { From } \\
\mathbf{1 3 . 0 2 . 2 0 1 5} \text { to } \\
\mathbf{0 5 . 0 5 . 2 0 1 5}\end{array}$ & $\begin{array}{c}\text { From } \\
\mathbf{2 6 . 0 9 . 2 0 1 5} \text { to }\end{array}$ & $\begin{array}{c}\text { From } \\
\mathbf{1 8 . 0 8 . 2 0 1 6} \text { to } \\
\mathbf{0 1 . 2 0 1 5}\end{array}$ & $\begin{array}{c}\text { From } \\
\mathbf{0 6 . 0 7 . 2 0 1 7} \text { to } \\
\mathbf{0 7 . 0 8 . 2 0 1 7}\end{array}$ & $\begin{array}{c}\text { From } \\
\mathbf{1 8 . 0 8 . 2 0 1 8} \text { to }\end{array}$ \\
\hline A of $L_{e q, 63 \mathrm{~Hz}}$ & 1.0 & 0.5 & -0.4 & 1.1 & 0.6 \\
A of $L_{e q, 125 \mathrm{~Hz}}$ & 0.2 & 0.1 & 0.0 & 0.1 & -0.1 \\
A of $\rho_{L, 2 \mathrm{NM}}$ & 0.8 & 0.7 & 0.6 & 0.6 & 1.0 \\
A of $\rho_{L, 5 \mathrm{NM}}$ & -1.7 & -3.0 & 1.1 & 0.4 & 2.0 \\
A of $\rho_{L, \text { Trieste }}$ & -1.6 & -2.8 & 1.1 & 0.2 & 1.4 \\
A of $\rho_{L, \text { Venice }}$ & -0.7 & -0.6 & 0.6 & 0.8 & 0.5 \\
A of $v_{v}$ & 1.1 & 1.2 & 0.8 & 1.1 & 2.4 \\
A of $h_{p}$ & 20.5 & 16.2 & 14.8 & 22.4 & 10.9 \\
\hline NM, nautical miles. & & & & &
\end{tabular}

brown curve presents ship density in the Gulf of Venice (Figures 2-6).

Many gaps in the ship densities in 2015 (evident in Figures 2 and 3) and one major gap (evident in October 2018 in Figure 6) were due to the reason that AIS System did not operate during these periods.
The red arrow on the diagram of average hourly ship densities (Figure 3 ) indicates dredging activities, which took place from 26 September 2015 to 26 October 2015. The red arrows on the diagram of average hourly ship densities (Figure 4) show cleaning activities at the seafloor in the canals of the Port of 


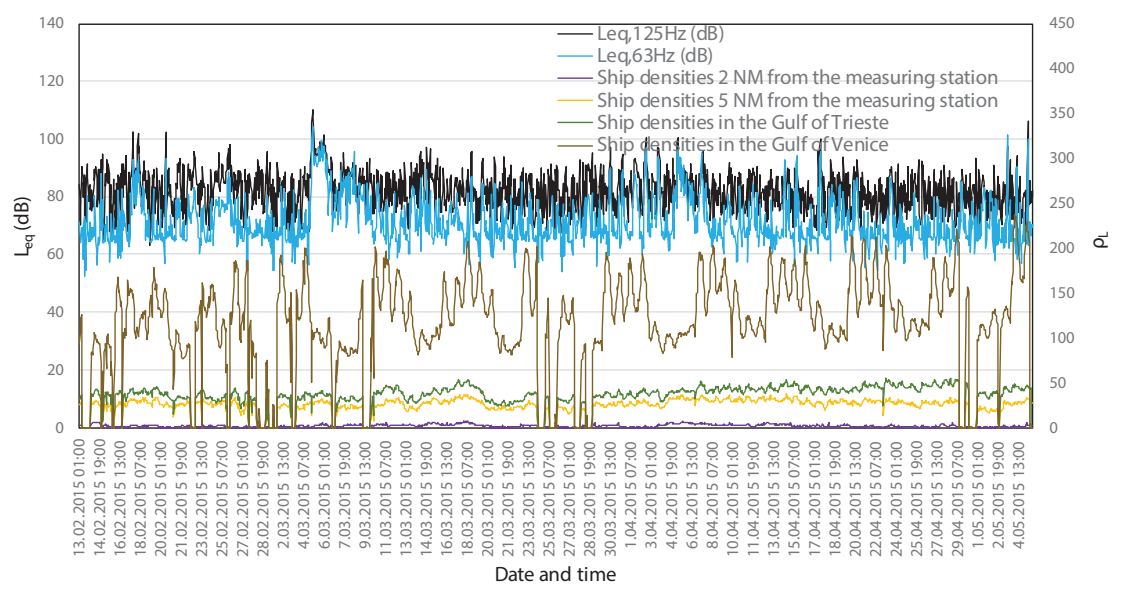

Figure 2: Diagram of the average hourly ship densities in the areas of 2 NM and 5 NM from the measuring station in the Gulf of Trieste and the Gulf of Venice in combination with the average hourly continuous underwater noise levels in 1/3-octave bands with centre frequencies of $63 \mathrm{~Hz}$ and $125 \mathrm{~Hz}$ (Leq) in the period from 12 February 2015 to 5 May 2015. NM, nautical miles.

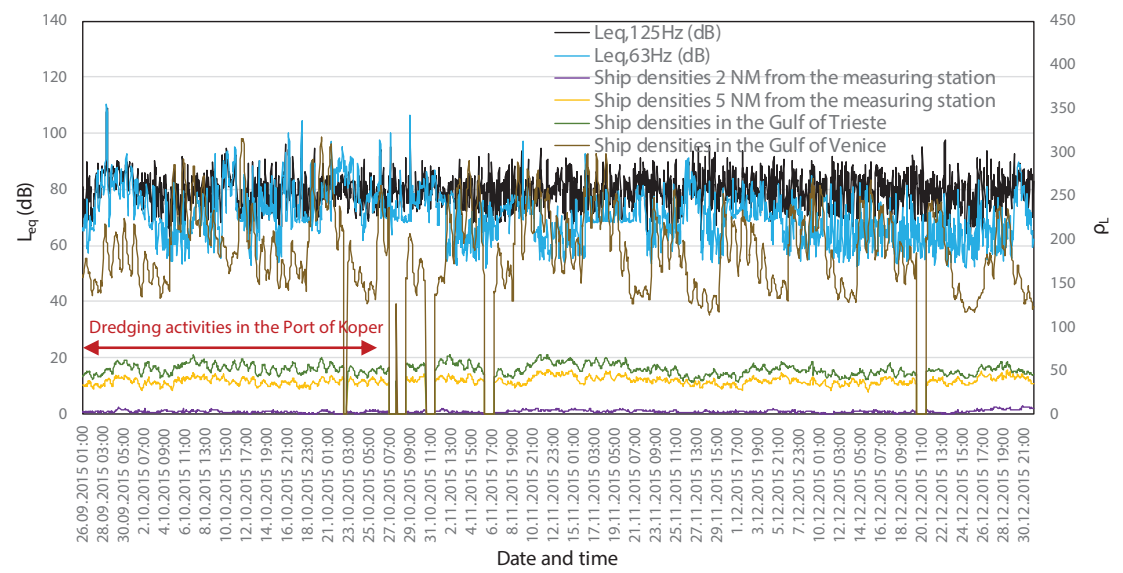

Figure 3: Diagram of the average hourly ship densities in the areas of 2 NM and 5 NM from the measuring station in the Gulf of Trieste and the Gulf of Venice in combination with the average hourly continuous underwater noise levels in 1/3-octave bands with centre frequencies of $63 \mathrm{~Hz}$ and $125 \mathrm{~Hz}\left(\mathrm{~L}_{\text {ed }}\right)$ during the period from 26 September 2015 to 31 December 2015. The red arrow indicates the period from 26 September 2015 to 26 October 2015, when dredging activities were done in the Port of Koper. NM, nautical miles.

Koper during the following periods: 18-31 August 2016 and 22-29 September 2016.

The results presented on these diagrams (Figures 2-6) are interpreted and discussed in the subsection Discussion.

The average equivalent continuous underwater noise levels in $1 / 3$-octave bands with centre frequencies of $63 \mathrm{~Hz}$ and $125 \mathrm{~Hz}$ were higher in the intervals by $\approx 11 \mathrm{~dB}\left(L_{e q, 63 \mathrm{~Hz}}\right)$ and $5 \mathrm{~dB}\left(L_{e q, 125 \mathrm{~Hz}}\right)$ when dredging activities took place than in the intervals when these activities were absent (Table 4). In addition, the average equivalent continuous underwater noise levels, were for $7 \mathrm{~dB}\left(L_{e q, 63 \mathrm{~Hz}}\right)$ and $7 \mathrm{~dB}\left(L_{e q, 125 \mathrm{~Hz}}\right)$, lower in the intervals, when cleaning activities took place than in the intervals when these activities were absent (Table 4).

The relationship of the measured ambient low-frequency noise levels with the meteorological factors is depicted in the diagrams (Figures 7-11) of the average hourly wind speeds and average hourly precipitation in each measuring period, in combination with the average hourly continuous underwater noise levels in 1/3-octave bands with centre frequencies of $63 \mathrm{~Hz}$ and $125 \mathrm{~Hz}$. Blue curve presents $L_{e q, 63 \mathrm{~Hz}}$ black curve 


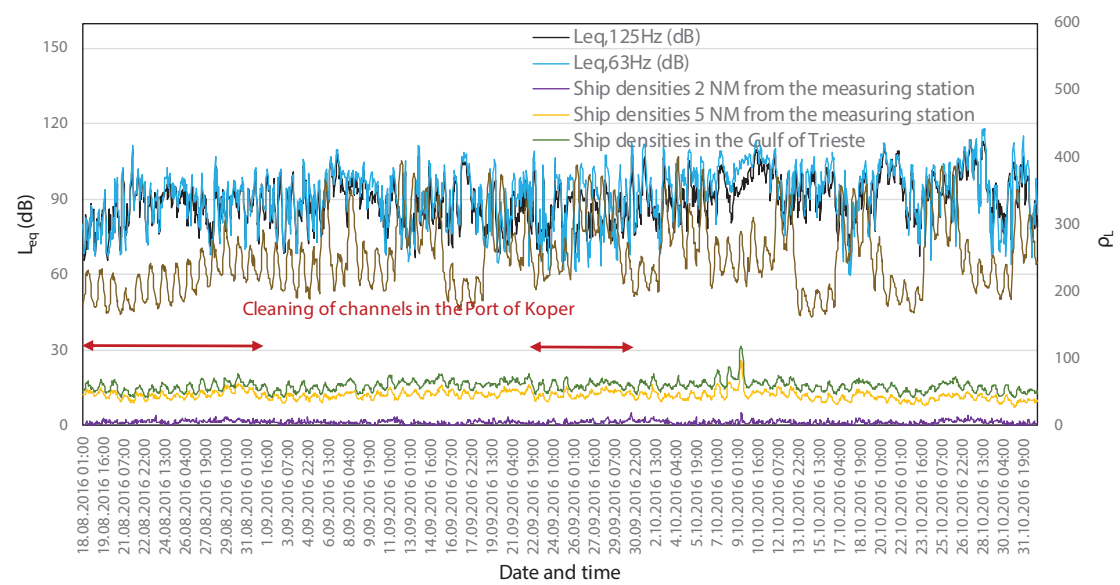

Figure 4. Diagram of the average hourly ship densities in the areas of 2 NM and 5 NM from the measuring station in the Gulf of Trieste and the Gulf of Venice in combination with the average hourly continuous underwater noise levels in 1/3-octave bands with centre frequencies of $63 \mathrm{~Hz}$ and $125 \mathrm{~Hz}\left(\mathrm{~L}_{e}\right)$ during the period from 18 August 2016 to 1 November 2016. The red arrows indicate the periods 18-31 August 2016 and 22-29 September 2016, during which cleaning of the channels in the Port of Koper was performed. NM, nautical miles.

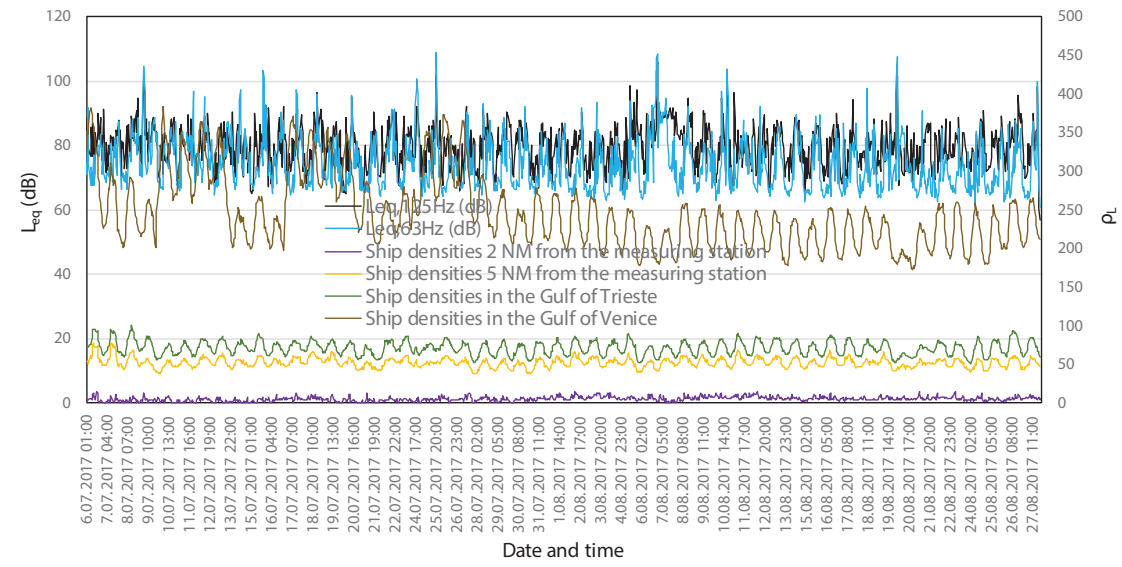

Figure 5. Diagram of the average hourly ship densities in the areas of 2 NM and 5 NM from the measuring station in the Gulf of Trieste and the Gulf of Venice in combination with the average hourly continuous underwater noise levels in 1/3-octave bands with centre frequencies of $63 \mathrm{~Hz}$ and $125 \mathrm{~Hz}\left(\mathrm{~L}_{\text {eq }}\right)$ during the period from 6 July 2017 to 27 August 2017. NM, nautical miles.

presents $L_{e q, 125 \mathrm{~Hz}}$ brown curve presents wind speed and green columns on the $\mathrm{x}$-axis present precipitation. The results presented in these diagrams (Figures 7-11) are discussed in the subsection Discussion.

\section{Discussion}

In this section, the relationship between the pressures in the Slovenian Sea that arise from anthropogenic activities (ship densities, dredging activities and cleaning of the seafloor) and the equivalent continuous levels of underwater noise in 1/3-octave bands with centre frequencies of $63 \mathrm{~Hz}\left(L_{e q, 63 \mathrm{~Hz}}\right)$ and $125 \mathrm{~Hz}\left(L_{e q, 125 \mathrm{~Hz}}\right)(\mathrm{dB})$ is discussed. Furthermore, the relationship between the continuous underwater noise levels and the meteorological parameters (wind speed $(\mathrm{m} / \mathrm{s})$ and precipitation $(\mathrm{mm})$ ) is also commented upon.

The average continuous underwater noise levels $\left(L_{e q, 63 \mathrm{~Hz}}\right.$ and $\left.L_{e q, 125 \mathrm{~Hz}}\right)$ measured in the Slovenian Sea (Table 2) were similar to those reported in the literature, which were found to be associated with the shipping noise [1-21]. Large variations of the $L_{e q, 63 \mathrm{~Hz}}$ levels were highly related to variations of the $L_{e q, 125 \mathrm{~Hz}}$ 


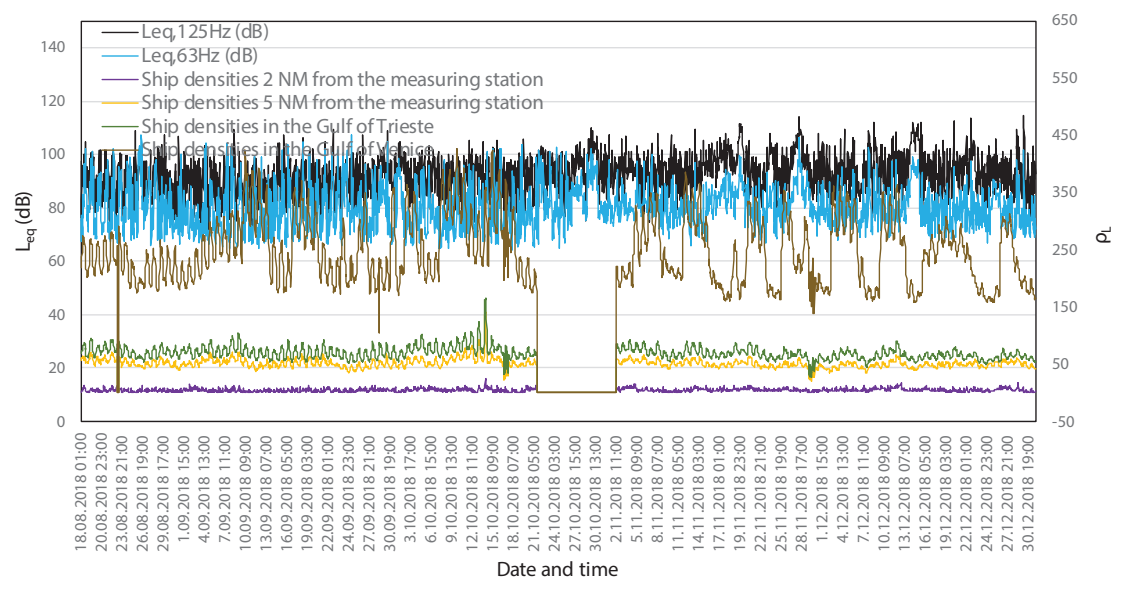

Figure 6: Diagram of the average hourly ship densities in the areas of 2 NM and 5 NM from the measuring station in the Gulf of Trieste and the Gulf of Venice in combination with the average hourly continuous underwater noise levels in 1/3-octave bands with centre frequencies of $63 \mathrm{~Hz}$ and $125 \mathrm{~Hz}\left(\mathrm{~L}_{\text {ed }}\right)$ in the period from 18 August 2018 to 31 December 2018. NM, nautical miles.

Table 4: The results of AVE and STDEV calculations of $L_{e q, 63 \mathrm{~Hz}}$ and $L_{e q, 125 \mathrm{~Hz}}$ in the periods with and without the anthropogenic activity

\begin{tabular}{|c|c|c|}
\hline $\begin{array}{l}\text { Type of the } \\
\text { anthropogenic } \\
\text { activity }\end{array}$ & $\begin{array}{l}A V E \& S T D E V \text { of } L_{e q, 63 \mathrm{~Hz}} \text { during the } \\
\text { period of anthropogenic activity }\end{array}$ & $\begin{array}{l}A V E \& S T D E V \text { of } L_{e q, 63 \mathrm{~Hz}} \text { during the } \\
\text { period without anthropogenic activity }\end{array}$ \\
\hline Dredging & $\begin{array}{l}26.9 .2015-26.10 .2015(7: 00-21: 00 \mathrm{~h}) \\
L_{e q, 63 \mathrm{~Hz}}=89.4 \pm 16.9 \mathrm{~dB} \text { re } 1 \mu \mathrm{Pa} \\
L_{e q, 125 \mathrm{~Hz}}=88.6 \pm 10.1 \mathrm{~dB} \text { re } 1 \mu \mathrm{Pa}\end{array}$ & $\begin{array}{l}26.9 .2015-26.10 .2015(22: 00-6: 00 \mathrm{hr}) \\
L_{e q, 63 \mathrm{~Hz}}=79.5 \pm 13.5 \mathrm{~dB} \text { re } 1 \mu \mathrm{Pa} \\
L_{e q, 125 \mathrm{~Hz}}=83.3 \pm 7.2 \mathrm{~dB} \text { re } 1 \mu \mathrm{Pa} \\
27.10 .2015-31.12 .2015(00: 00-24: 00 \mathrm{hr}) \\
L_{e q, 63 \mathrm{~Hz}}=78.5 \pm 12.9 \mathrm{~dB} \text { re } 1 \mu \mathrm{Pa} \\
L_{e q, 125 \mathrm{~Hz}}=83.5 \pm 7.0 \mathrm{~dB} \text { re } 1 \mu \mathrm{Pa}\end{array}$ \\
\hline $\begin{array}{l}\text { Cleaning of the } \\
\text { seafloor }\end{array}$ & $\begin{array}{l}\text { 18.8.2016-31.8.2016 (8:00-16:00) } \\
22.9 .2016-29.9 .2016(8: 00-16: 00) \\
L_{e q, 63 \mathrm{~Hz}}=94.3 \pm 12.3 \mathrm{~dB} \text { re } 1 \mu \mathrm{Pa} \\
L_{e q, 125 \mathrm{~Hz}}=90.6 \pm 8.6 \mathrm{~dB} \text { re } 1 \mu \mathrm{Pa}\end{array}$ & $\begin{array}{l}18.8 .2016-31.8 .2016(17: 00-7: 00) \\
22.9 .2016-29.9 .2016(17: 00-7: 00) \\
30.9 .2016-1.11 .2016(00: 00-24: 00 \mathrm{hr}) \\
L_{e q, 63 \mathrm{~Hz}}=101.4 \pm 14.7 \mathrm{~dB} \text { re } 1 \mu \mathrm{Pa} \\
L_{e q, 125 \mathrm{~Hz}}=97.7 \pm 12.5 \mathrm{~dB} \text { re } 1 \mu \mathrm{Pa}\end{array}$ \\
\hline
\end{tabular}

AVE, average value; STDEV, standard deviation.

levels (Figures 2-6). Average hourly continuous underwater noise levels $\left(L_{e q, 63 \mathrm{~Hz}}\right.$ and $\left.L_{e q, 125 \mathrm{~Hz}}\right)$ presented in Figures 2-6 show that the levels of $L_{e q, 63 \mathrm{~Hz}}$ were, for most of the measured days, lower than $L_{e q, 125 \mathrm{~Hz}}$ which is in accordance with the data presented in Table 2. This can be explained by the fact that the propagation of underwater noise in the shallow seawater at $63 \mathrm{~Hz}$ is lower than that at $125 \mathrm{~Hz}$.

The results of this study showed that average equivalent continuous underwater noise levels were higher in the intervals by $11 \mathrm{~dB}($ Leq, $63 \mathrm{~Hz})$ and $5 \mathrm{~dB}$ (Leq,125 Hz) when dredging activities took place, than in the intervals when these activities were absent. Furthermore, the average equivalent continuous underwater noise levels were found to be lower in the intervals when cleaning activities took place, than when such activities were absent (Table 4). This finding indicated that cleaning activities were not related to the underwater noise levels. This might be explained by the fact that cleaning of the seafloor was performed with an excavator from the mainland.

The lowest average ship densities were measured within the areas of the radii of 


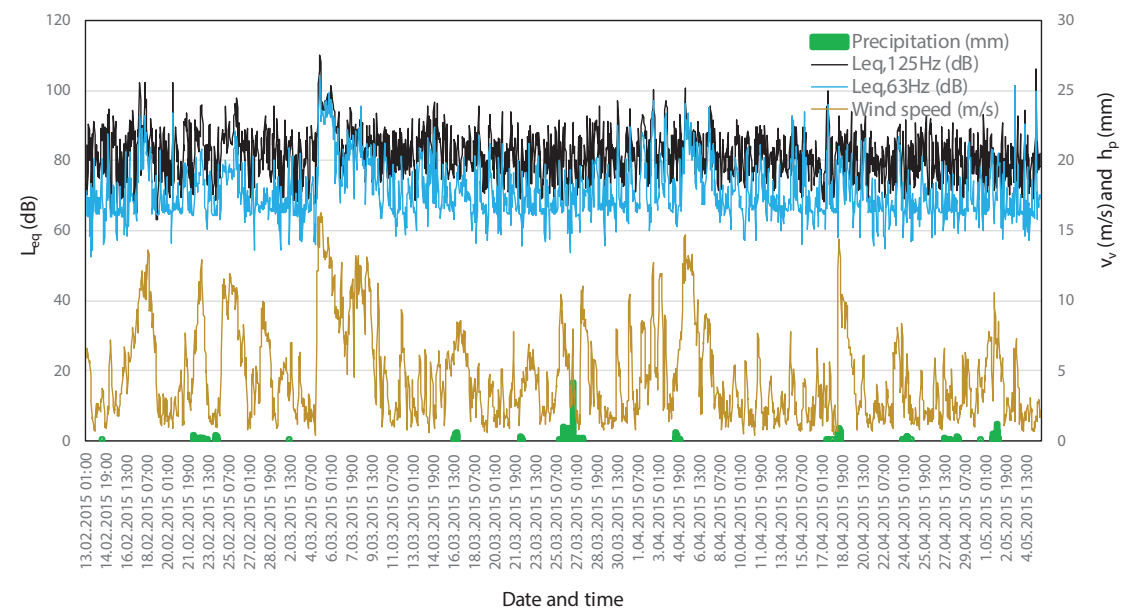

Figure 7: Diagram of the average hourly wind speeds $\left(v_{v}\right)$ and average hourly precipitation $\left(h_{p}\right)$ in combination with the average hourly continuous underwater noise levels in 1/3-octave bands with centre frequencies of $63 \mathrm{~Hz}$ and $125 \mathrm{~Hz}\left(L_{e q}\right)$ during the period from 12 February 2015 to 5 May 2015.

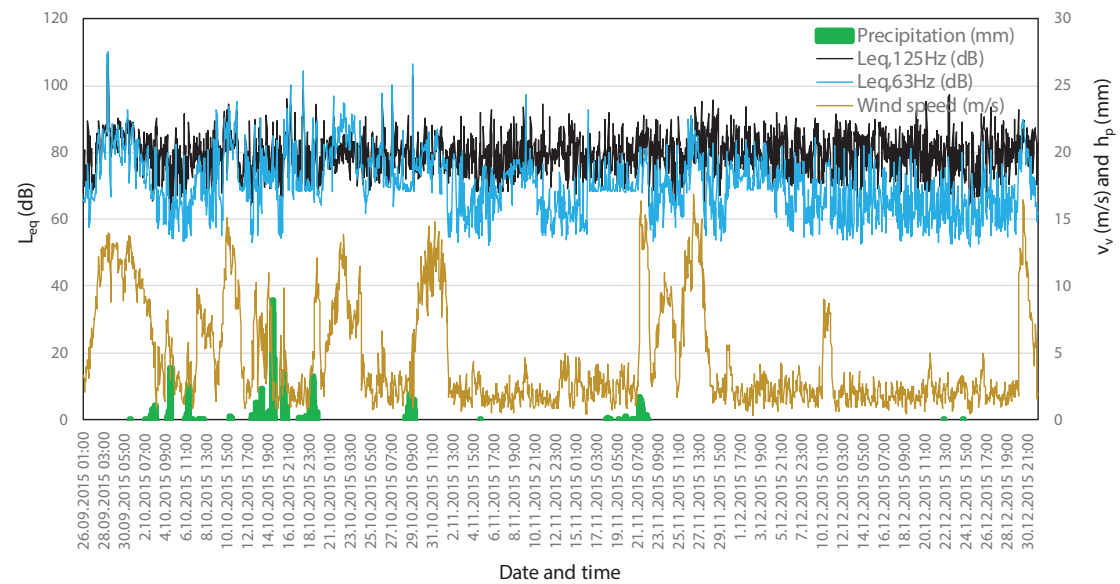

Figure 8: Diagram of the average hourly wind speeds $\left(v_{v}\right)$ and average hourly precipitation $\left(h_{p}\right)$ in combination with the average hourly continuous underwater noise levels in 1/3-octave bands with centre frequencies of $63 \mathrm{~Hz}$ and $125 \mathrm{~Hz}\left(L_{e q}\right)$ in the period from 26 September 2015 to 31 December 2015.

$2 \mathrm{NM}$ and $5 \mathrm{NM}$ from the measuring station, while higher ship densities were observed in the Gulf of Trieste; the maximum ship densities were observed in the Gulf of Venice, as expected (Table 2). The most likely reason underlying the fact that variation in underwater noise levels was partly related to the variation of the ship densities (Figures 2-6), could be the relatively small acoustic propagation in the shallow sea [45, 46]. Acoustic propagation in shallow water environments was reported to be complex because of interference due to seafloor and sea surface sound reflections and sound transmission losses [47, 48]. Shallow water channels do not allow propagation of low-frequency signals due to the wave-guide effect; this implies that there would be a lower cut-off frequency below which sound waves would not propagate, since the sound propagates into the sea bed $[49,50]$. This phenomenon leads to the less significant contribution of shipping to underwater noise.

Figures 7-11 demonstrate that precipitation is not greatly associated with the fluctuations in continuous underwater noise levels, while some larger deviations in the wind speed are associated with the larger fluctuations in continuous underwater noise levels. This could be explained by the fact that wind blowing over the sea generates waves that, 


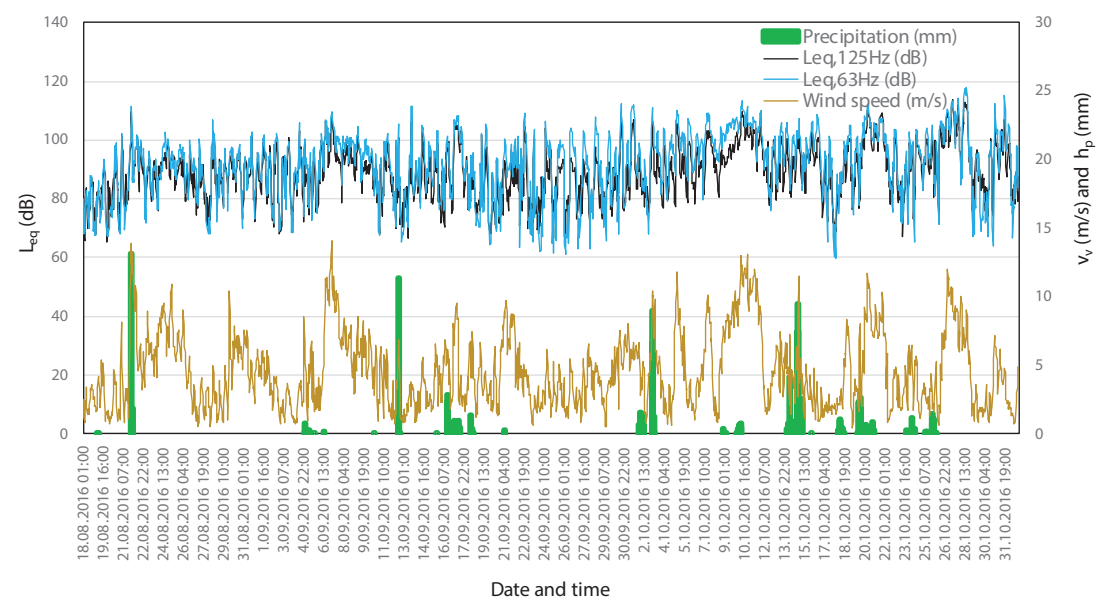

Figure 9: Diagram of the average hourly wind speeds $\left(v_{v}\right)$ and average hourly precipitation $\left(h_{p}\right)$ in combination with the average hourly continuous underwater noise levels in 1/3-octave bands with centre frequencies of $63 \mathrm{~Hz}$ and $125 \mathrm{~Hz}\left(L_{e q}\right)$ in the period from 18 August 2016 to 1 November 2016.

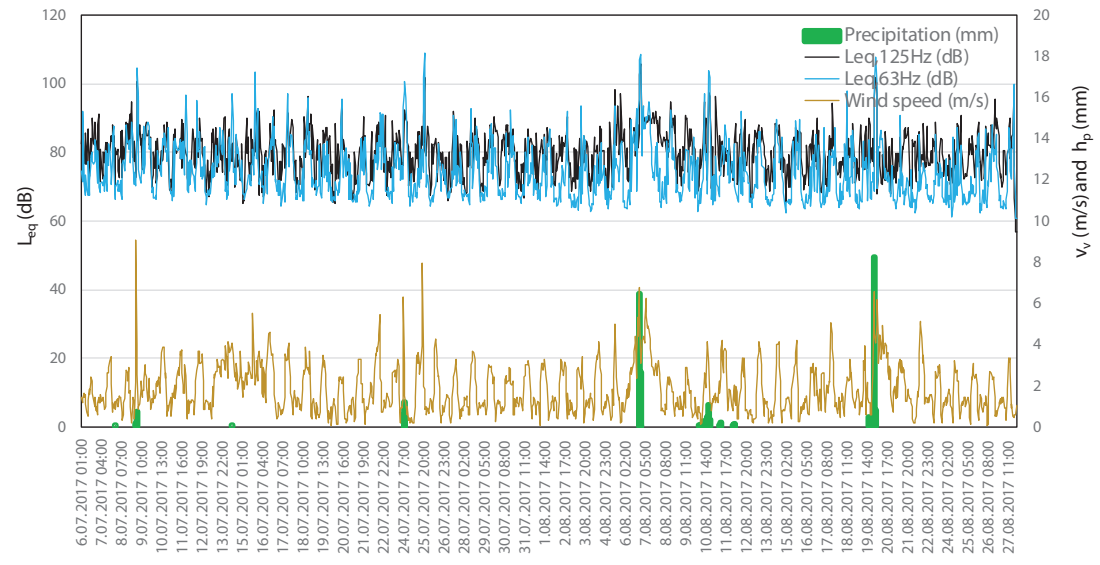

Date and time

Figure 10: Diagram of the average hourly wind speeds $\left(v_{v}\right)$ and average hourly precipitation $\left(h_{p}\right)$ in combination with the average hourly continuous underwater noise levels in 1/3-octave bands with centre frequencies of $63 \mathrm{~Hz}$ and $125 \mathrm{~Hz}\left(\mathrm{~L}_{e q}\right)$ in the period from 6 July 2017 to 27 August 2017.

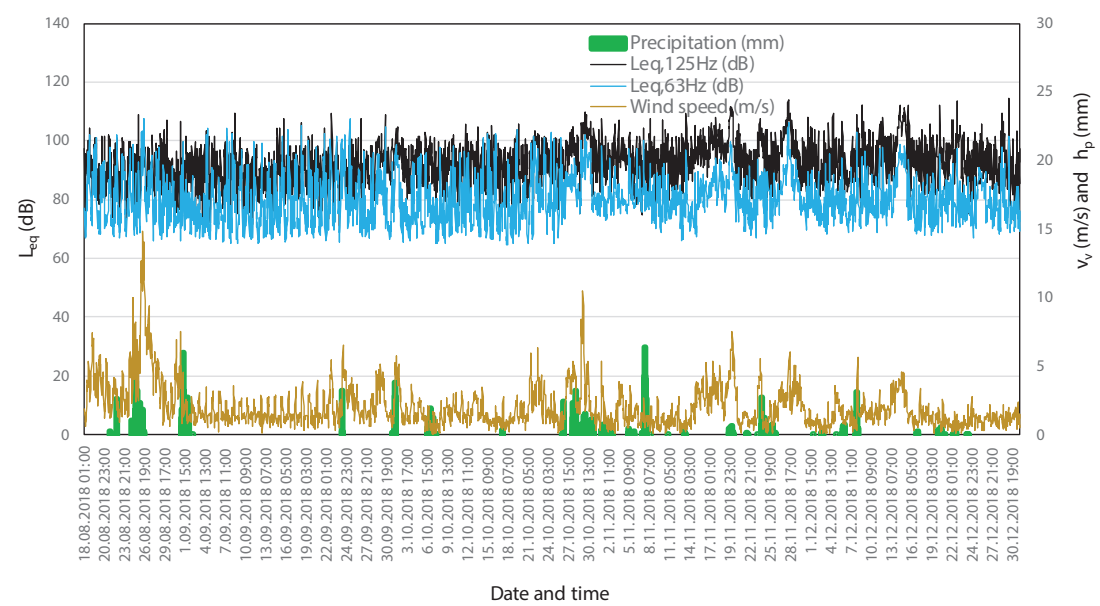

Figure 11: Diagram of the average hourly wind speeds $\left(v_{v}\right)$ and average hourly precipitation $\left(h_{p}\right)$ in combination with the average hourly continuous underwater noise levels in 1/3-octave bands with centre frequencies of $63 \mathrm{~Hz}$ and $125 \mathrm{~Hz}\left(\mathrm{~L}_{e q}\right)$ in the period from 18 August 2018 to 31 December 2018. 
when they are large enough, break and produce underwater sound. This phenomenon is well described in several previous studies $[7,9,22-25]$.

\section{Conclusion}

The results of our study have indicated that the underwater noise levels in the Slovenian Sea are related to dredging activity in the Port of Koper and are partly related to variations of the ship densities. Some larger deviations in the wind speed were found to be associated with the larger fluctuations in continuous underwater noise levels, while precipitation was not related to the underwater noise. Use of larger data sets is suggested to ensure that it becomes possible to further study and evaluate underwater noise levels in relation to manmade or natural sound sources.

\section{Acknowledgements}

The current study was funded by the Ministry for the Environment and Spatial Planning, Slovenia. The AIS data from the year 2015 were obtained by the BALMAS project partnership. The AIS data from 2016 to 2018 were obtained by the Slovenian Maritime Administration in the frame of the Ministry for Infrastructure.

\section{References}

[1] Southall, B.L., Scholik-Schlomer, A.R., Hatch, L., Bergmann, T., Jasny, M., Metcalf, K., Weilgart, L., Wright A.J. (2017): Underwater noise from large commercial ships-International Collaboration for Noise Reduction. In: Encyclopedia of Maritime and Offshore Engineering, John Wiley \& Sons, DOI:10.1002/9781118476406.emoe056.

[2] Garrett, J.K., Blondel, P., Godley, B.J., Pikesley, S.K., Witt, M.J., Johanning, L. (2016): Long term underwater sound measurements in the shipping noise indicator bands $63 \mathrm{~Hz}$ and $125 \mathrm{~Hz}$ from the port of Falmouth Bay, UK. Marine Pollution Bulletin, 110(1), pp. 438-448, DOI:10.1016/j.marpolbul.2016.06.021.

[3] Merchant, N.D., Blondel, P., Dakin, D.T., Dorocicz, J. (2012): Averaging underwater noise levels for environmental assessment of shipping. The Journal of the Acoustical Society of America, 132(4), pp. 343-349, DOI:10.1121/1.4754429.

[4] Abrahamsen, K., Norway, H. (2012): The ship as an underwater noise source. In: Proceedings of the 11th European Conference on Underwater Acoustics. Edinburgh, Scotland, 02-06 July 2012, DOI:10.1121/1.4772953.

[5] McKenna, M.F., Ross, D., Wiggins, S.M., Hildebrand, J.A. (2012): Underwater radiated noise from modern commercial ships. The Journal of Acoustical Society of America, 131(1), pp. 92-103, DOI:10.1121/1.3664100.

[6] Bardyshev, V.I. (2008): Underwater surf noise near sea coasts of different types. Acoustical Physics, 54(6), pp. 939-948, DOI:10.1134/ S1063771008060109.

[7] Dahl, P.H., Miller, J.H., Cato, F.H., Andrew, R.K. (2007): Underwater ambient noise. Acoustics Today, 3(1), pp. 23-33.

[8] Wenz, G.M. (1962): Acoustic ambient noise in the ocean: Spectra and sources. The Journal of the Acoustical Society of America, 34(12), pp. 19361956, DOI:10.1121/1.1909155.

[9] National Research Council. (2003): Committee on potential impacts of ambient noise in the ocean on marine mammals. Ocean Noise and Marine Mammals. National Academies Press: Washington.

[10] Estabrook, B.J., Ponirakis, D.W., Clark, C.W., Rice, A.N. (2016): Widespread spatial and temporal extent of anthropogenic noise across the Northeastern Gulf of Mexico shelf ecosystem. Endangered Species Research, 30, pp. 267-282, DOI:10.3354/esr00743.

[11] Wenz, G.M. (1971): Review of underwater acoustic research: noise. The Journal of the Acoustical Society of America, 51(3B), pp. 1010-1024, DOI:10.1121/1.1912921.

[12] Wales, S.C., Heitmeyer, R.M. (2002): An ensemble source spectra model for merchant shipradiated noise. The Journal of the Acoustical Society of America, 111(3), pp. 1211-1231, DOI:10.1121/1.1427355.

[13] Andrew, R.K., Howe, B.M., Mercer, J.A., Dzieciuch, M.A. (2002): Ocean ambient sound: Comparing the 1960 s with the 1990s for a receiver off the California coast. Acoustics Research Letters, 3(2), pp. 65-70, DOI:10.1121/1.1461915.

[14] McDonald, M.A., Hildebrand, J.A., Wiggins, S.M. (2006): Increases in deep ocean ambient noise in the Northeast Pacific west of San Nicolas Island, California. The Journal of the Acoustical 
Society of America, 120(2), pp. 711-718, DOI:10.1121/1.2216565.

[15] Ross Chapman, N., Price, A. (2011): Lowfrequency deep ocean ambient noise trend in the Northeast Pacific Ocean. The Journal of the Acoustical Society of America, 129(5), pp. 161-165, DOI:10.1121/1.3567084.

[16] Andrew, R.K., Howe, B.M., Mercer, J.A. (2011): Longtime trends in ship traffic noise for four sites off the North American West Coast. The Journal of the Acoustical Society of America, 129(2), pp. 642-651, DOI:10.1121/1.3518770.

[17] Miksis-Olds, J.L., Nichols S.M. (2016): Is low-frequency ocean sound increasing globally. The Journal of the Acoustical Society of America, 139(1), pp. 501-511, DOI:10.1121/1.4938237.

[18] United Nations (2020): Review of Maritime Transport 2019. United Nations Conference on Trade and Development, United Nations Publication, pp. 132.

[19] United Nations (2019): Handbook of Statistics 2019 Maritime transport, United Nations Conference on Trade and Development, United Nations Publication.

[20] Berns, S.G., Dragt, J., Van Bergen, T. (2015): Global Trends to 2030 - Impact on Port Industry. Deloitte: China.

[21] EUROSTAT - European statistics [online]. Renewed (2/22/2021) [cited 2/25/2021]. Available on: http://ec.europa.eu/eurostat/data/database.

[22] Prosperetti, A. (1988): Bubble-related ambient noise in the ocean. The Journal of the Acoustical Society of America, 84(3), pp. 1024-1054, DOI:10.1121/1.396740.

[23] Carey, W.M., Browning, D.G. (1988): Low-frequency ocean ambient noise: Measurements and theory. In: Sea Surface Sound. Kerman, B.R. (ed.). Kluwer Academic: Dordrecht, pp. 361-376.

[24] Banner, M.L., Cato, D.H. (1993): Physical mechanisms of noise generation by breaking waves - a laboratory study. In: Natural Physical Sources of Underwater Sound - Sea Surface Sound (2nd Edition), Kerman, B.R. (ed.). Kluwer Academic: Dordrecht, pp. 429-436.

[25] Medwin, H., Beaky, M.M. (1989): Bubble sources of the Knudsen sea noise spectra. The Journal of the Acoustical Society of America, 89, pp. 1124-1130, DOI:10.1121/1.398104.

[26] Ma, B.B., Nystuen, J.A., Lien, R.C. (2005): Prediction of underwater sound levels from rain and wind. The Journal of the Acoustical Society of America, 177(6), pp. 3555-3565, DOI:10.1121/1.1910283.
[27] Marley, S.A., Salgado Kent, C.P., Erbe, C., Parnum, I.M. (2017): Effects of vessel traffic and underwater noise on the movement, behavior, and vocalizations of bottlenose dolphins in an urbanized estuary. Scientific Reports, 7(1), pp. 13437, DOI:10.1038/ s41598-017-13252-z.

[28] Knudsen, V.O., Alford, R.S., Emling, J.W. (1962): Underwater ambient noise. Journal of Marine Research, 7(3), pp. 410-429.

[29] Fish, M.P. (1964): Biological sources of sustained ambient sea noise. In: Marine Bio-Acoustics, Tavolga, W.N. (ed.). Pergamon: Oxford.

[30] Cato, D.H. (1978): Marine biological choruses observed in tropical waters near Australia. The Journal of the Acoustical Society of America, 64(3), pp. 736-743, DOI:10.1121/1.382038.

[31] Au, W.W., Mobley, J., Burgess, W.C., Lammers, M.O., Nachtigall. P.E. (2000): Seasonal and diurnal trends of chorusing humpback whales wintering in waters off Western Maui. Marine Mammal Science, 16(3), pp. 530-544, DOI:10.1111/j.1748-7692.2000.tb00949.x.

[32] Erbe, C. (2002): Underwater noise of whale-watching boats and potential effects on killer whales (Orcinus orca), based on an acoustic impact model. Marine Mammal Science, 18(2), pp. 394-418, DOI:10.1111/j.1748-7692.2002.tb01045.x.

[33] Hallers-Tjabbes, C.C. (2007): Underwater noise from maritime sources and impact on marine life. WMU Journal of Maritime Affairs, 6(2), pp. 225-233, DOI:10.1007/BF03195117.

[34] Directive of the European Parliament and of the Council (2008/56): Establishing a framework for community action in the field of marine environmental policy (Marine Strategy Framework Directive), Official Journal of the European Union, 25. 6. 2008, L164, pp. 19-40.

[35] IMO, MEPC.1/Circ.833 (2014): Guidelines for the reduction of underwater noise from commercial shipping to address adverse impacts on marine life. International Maritime Organization (IMO), London, pp. 6.

[36] Water Act (2015): Official Gazette of the Republic of Slovenia, No. 67/2002, 57/2008, 57/2012, 100/2013, 40/2014 and 56/2015, pp. 117.

[37] Decree on the detailed content of the Marine management plan (2013): Official Gazette of the Republic of Slovenia, No. 92/2010 and 20/2013, pp. 13.

[38] Deželak, F., Čurović, L., Jenko, J. (2015): Strokovne podlage za vzpostavitev sistema nadzora nad podvodnim hrupom v skladu z Direktivo o morski strategiji (2008/56/ES), Rezultati četrtletnih 
kontinuiranih meritev podvodnega hrupa na merilni postaji, Inštitut za vode Republike Slovenije, Ljubljana, pp. 22.

[39] Popit, A., Zupančič, G. (2018): Brief review of the Slovenian approach to data pre-processing, data processing and presentation of noise indicator data. Quietmed Project Internal Report.

[40] Bruel \& Kjaer (2016): Hand-held analyzer types 2250, 2250-L and 2270. Instruction Manual, pp. 140.

[41] Robinson, S.P., Lepper, P.A., Hazelwood, R.A. (2014): Good practice guide no. 133 - Underwater noise measurement. National Physical Laboratory. pp. 95.

[42] Commission Decision laying down criteria and methodological standards on good environmental status of marine waters and specifications and standardized methods for monitoring and assessment, and repealing Decision 2010/477/EU (EC/2017/848): Official Journal of the European Union, 18. 5. 2017, L125, pp. 43-74.

[43] Dekeling, R., Tasker, M., Van der Graaf, S., Ainslie, M., Andersson, M., André, M., Borsani F., Brensing, K., Castellote, M., Cronin, D., Dalen, J., Folegot, T., Leaper, R., Pajala, J., Redman, P., Robinson, S., Sigray, P., Sutton, G., Thomsen, F., Werner, S., Wittekind, D., Young, J.V. (2014): Monitoring guidance for underwater noise in European Seas, Part I: Executive Summary, JRC Scientific and Policy Report, EUR 26557 EN, Publications Office of the European Union, Luxembourg, pp. 16.
[44] Pirc, S. (1997): Statistika v geologiji: Učni pripomoček. Univerza v Ljubljani, Naravoslovnotehniška fakulteta, Oddelek za geologijo, Ljubljana, pp. 59.

[45] Merchant, N.D., Brookes, K.L., Faulkner, R.C., Bicknell, A.W.J., Godley, B.J., Witt, M.J. (2016): Underwater noise levels in UK waters. Scientific Reports, 6, 36942, DOI:10.1038/srep36942.

[46] Kozaczka, E., Grelowska, G. (2018): Propagation of ship-generated noise in shallow sea. Polish Maritime Research, 25, pp. 37-46, DOI:10.2478/ pomr-2018-0052.

[47] Meyer, V., Audoly, C. (2017): A comparison between experiments and simulation for shallow water short range acoustic propagation. In: ICSV 24th, International Congress on Sound and Vibration, London, United Kingdom.

[48] Duncan, A.J., Gavrilov, A.N., McCauley, R.D, Parnum, I.M. (2013): Characteristics of sound propagation in shallow water over an elastic seabed with a thin cap-rock layer, The Journal of the Acoustical Society of America, 134(1), pp. 207-215, DOI:10.1121/1.4809723.

[49] Urick, R.J. (1983): Principles of underwater sound. 3rd edn. McGraw-Hill: New York.

[50] Robinson, S.P., Lepper, P.A. (2013): Scoping study: Review of current knowledge of underwater noise emissions from wave and tidal stream energy devices. Technical Report, September 2013, The Crown Estate: London, pp. 71. 